\section{Hiperparatireoidismo primário: importante confirmar primeiro, localizar depois}

Maria Lucia Fleiuss de Farias'

$\mathrm{N}$ Tíveis sanguíneos de paratormônio acima da faixa normal são um achado frequente na investigação de osteopenia/osteoporose em pacientes idosos, especialmente no sexo feminino. É justamente neste último grupo que encontraremos a maioria dos casos de hiperparatireoidismo primário; por outro lado, é nos idosos em geral que encontraremos frequentemente o hiperparatireoidismo secundário à carência de vitamina D. Somente após termos certeza da autonomia funcional de uma ou mais paratireoides é que devemos passar aos testes de imagem para guiar o cirurgião; jamais antes, jamais para confirmar tratar-se de hiperparatireoidismo primário, pois que todos esses testes têm suas limitações e podem ser negativos mesmo nos casos de adenoma único da paratireoide.

Neste número dos ABE\&M, Oliveira e cols. abordam esses temas de forma bastante didática, mostrando suas experiências com o diagnóstico e com os testes localizatórios $\mathrm{da}(\mathrm{s})$ paratireoide(s). O diagnóstico baseia-se na concomitância de hipercalcemia e PTH elevado, e a deficiência de vitamina $\mathrm{D}$, reconhecida nos idosos brasileiros (1), deve ser pesquisada nos casos de calcemia limítrofe. Lembramos que os níveis adequados de 25-hidroxivitamina $\mathrm{D}$ nos idosos são estimados em não menos que 90-100 mmoles $(36-40 \mathrm{ng} / \mathrm{ml})(2,3)$ e que muitos meses de reposição de doses adequadas de vitamina $\mathrm{D}$ podem ser necessários para reverter o hiperparatireoidismo secundário. A reposição está autorizada mesmo na impossibilidade de dosarmos 25-hidroxivitamina $\mathrm{D}$, sem medo de intoxicação desde que sigamos os níveis de cálcio em sangue e urina. O progressivo declínio da filtração glomerular no envelhecimento pode contribuir para a elevação do PTH, mas essa influência não foi considerada significativa no estudo de Need e cols. (4); segundo os autores, o principal determinante do hiperparatireoidismo nos idosos é o declínio de vitamina D.

Quanto aos métodos de imagem, também é nossa experiência que um simples ultrassom pode identificar um volumoso adenoma único de paratireoide, mas que todos os recursos devem ser utilizados em casos duvidosos, especialmente nas reintervenções, em pacientes não curados na primeira abordagem cirúrgica. Yip e cols (5) classificam os resultados do Sestamibi ( 2 momentos) associado ao SPECT em: $0=$ negativo, 1 = possível, 2 = provável, 3 = certamente adenoma, ou 4 = doença multiglandular. $\mathrm{O}$ adenoma único foi achado em $211 / 262$ (81\%) daqueles 0-1 versus 263/288 (91\%) dos 2-3 ( $\mathrm{p}<0,001)$; doença multiglandular foi confirmada em 31/144 (22\%) pacientes grau 0 versus $13 / 166(8 \%)$ pacientes grau $3(\mathrm{p}=0,0005)$; por outro lado, somente $7 / 27(26 \%)$ pacientes classificados como 4 tinham realmente doença multiglandular. Outra recente publicação enfatiza a vantagem de associar todos os métodos de imagem até que se esgotem as possibilidades de localização pré-operatória (6).

Em tese, e principalmente na segunda intervenção cirúrgica, concordamos.
1 Professora de Endocrinologia, Universidade Federal do Rio de Janeiro (UFRJ), Rio de Janeiro, RJ, Brasil

Correspondência para: Maria Lucia Fleiuss de Farias Rua Santa Clara, 195, ap. 501 22041-012 - Rio de Janeiro, RJ, Brasil

fleiuss@hucff.ufr..br 


\section{REFERÊNCIAS}

1. Saraiva GL, Cendoroglo MS, Ramos LR, Araújo LMQ, Vieira JGH, Maeda SS, et al. Prevalência da deficiência, insuficiência de vitamina $D$ e hiperparatireoidismo secundário em idosos institucionalizados e moradores na comunidade da cidade de São Paulo, Brasil. Arq Bras Endocrinol Metab. 2007;51:437-42.

2. Lips P. Vitamin D deficiency and secondary hyperparathyroidism in the elderly: consequences for bone loss and fractures and therapeutic implications. Endocr Rev. 2001;22:477-501.

3. Bischoff-Ferrari HA, Giovannucci E, Willett WC, Dietrich T, Dawson-Hugues B. Estimation of optimal serum concentrations of 25-hydroxyvitamin D for multiple health outcomes. Am J Clin Nutr. 2006;84:18-28.

4. Need AG, O'Loughlin PD, Morris HA, Horowitz M, Nordin BEC. The effects of age and other variables on serum parathyroid hormone in postmenopausal women attending an osteoporosis center. J Clin Endocrinol Metab. 2004;89:1646-9.

5. Yip L, Pryma DA, Yim JH, Carty SE, Ogilvie JB. Sestamibi SPECT intensity scoring system in sporadic primary hyperparathyroidism. World J Surg. 2009;33:426-33.

6. Wimmer G, Profanter C, Kovacs P, Sieb M, Gabriel M, Putzer D, et al. CT-MIBI-SPECT image fusion predicts multiglandular disease in hyperparathyroidism. Langenbecks Arch Surg. 2010;395:73-80. 